\title{
REFLEKSI PARADIGMA KEDAULATAN PANGAN DI INDONESIA: STUDI KASUS GERAKAN PANGAN LOKAL DI FLORES TIMUR
}

\author{
${ }^{1}$ Adi Nugraha, ${ }^{2}$ Mochammad Subkhi Hestiawan, ${ }^{3}$ Dika Supyandi \\ 1,3 Departemen Sosial Ekonomi, Fakultas Pertanian Universitas Padjajaran, \\ ${ }^{2}$ Alumni Wageningen University \\ Email: adi.nugraha@unpad.ac.id
}

\begin{abstract}
ABSTRAK
Kedaulatan Pangan telah diadopsi sebagai pendekatan pembangunan pangan dan pertanian nasional bersama dengan konsep kemandirian pangan dan ketahanan pangan. Namun, Program yang diinisiasi pemerintah lebih dipengaruhi oleh paradigma ketahanan pangan dan kemandirian pangan yang lebih rentan terhadap rezim korporasi pangan. Kedaulatan pangan perlu lebih jauh didiseminasikan sebagai alternatif terhadap rezim korporasi pangan. Studi ini merupakan studi kualitatif deskriptif yang menggunakan pendekatan etnografis dalam pengambilan informasi. Kajian terhadap Persepsi terhadap operasionalisasi konsep kedaulatan pangan di tingkat petani dapat diungkap secara lebih detail salah satunya dengan teori Hegemoni Gramsci, analisa regim pangan, dan teori multi kedaulatan. Hasil kajian menunjukkan bahwa respon petani terhadap kedaulatan pangan dan ketahanan pangan cenderung samar dan menunjukkan keterkaitan yang sejajar nonkomplementer. Kedaulatan dapat bekerja baik dalam kondisi yang menghargai adanya keberagaman sumber kedaulatan. Kedaulatan pangan memiliki kecenderungan untuk dapat menguatkan keberagaman konteks, budaya, dan pilihan cara produksi sebagai upaya nyata untuk mengurangi dampak dominasi regim pangan korporasi terhadap upaya negara dan petani menjamin terpenuhinya hak rakyat atas pangan.
\end{abstract}

Kata kunci: kedaulatan pangan, ketahanan pangan, rezim korporasi pangan, gerakan petani

\section{ABSTRACT}

Food sovereignty has been officially adopted as national food and agriculture development approach along with food self sufficiency and food security. However, state led program were heavily influence by food security paradigm and food self-sufficiency which more vulnerable to predatory character of corporate food regime. The food sovereignty discourse must be disseminated further as alternative to corporate food regime. The discourse of food sovereignty was put into the action by NGO and local groups which framed as local food movement initiative. The local food movement and the phenomena surrounding its rise needs to be ethnographically scrutinized. Gramsci's theory of hegemony, food regime analysis, relational scale and multiple sovereignty elucidate the perception of food sovereignty value concept its relation and contestation among small scale in the Flores Timur. Results shows that in small scale farmer perceived food sovereignty and food security are interrelated because the persistence penetration of neoliberal economy. Food sovereignty should be articulated and adapted for different contexts without losing its ground. Food sovereignty works best with multiple recognitions of sovereignty. Food sovereignty were embrace and strengthen the diversity of contexts, cultures and pathways in order to slow down the further domination of the corporate food regime.

Keywords: food sovereignty, food security, corporate food regime, farmer's movement

\section{PENDAHULUAN}

Kebijakan pangan indonesia sangat dipengaruhi oleh apa yang disebut oleh McMichael (2009) sebagai rezim pangan. Rezim pangan di indonesia ditandai oleh fenomena yang mewarnai arah kebijakan pangan Indonesia, yaitu agribisnis kolonial, revolusi hijau, politik dumping harga pangan, liberalisasi pertanian dan yang terbaru adalah penguasaan pangan oleh segelintir korporasi. Dominasi korporasi pangan sangat dimungkinkan, bahkan difasilitasi oleh pemerintah di masa lalu terutama di masa orde baru. Dominasi korporasi pangan yang difasilitasi oleh pemerintah telah menyebabkan tidak maksimalnya pemanfaatan keunggulan 
komparatif nasional berupa keberagaman sumber daya hayati, pengetahuan lokal dan iklim. Bahkan, tidak dapat dipungkiri dominasi logika pertanian telah memicu kesenjangan akses terhadap pangan dan akumulasi serta polarisasi kekuasaan dan modal pada korporasi. Akibatnya, Indonesia secara umum menjadi sangat tergantung terhadap impor pangan dan fluktuasi perdagangan global pangan.

Ketahanan pangan dan swasembada menjadi konsep yang mendominasi kebijakan pangan pemerintah. Ketahanan pangan merupakan paradigma yang secara resmi digunakan pemerintah dalam pemenuhan pangan penduduk dan pertanian terkait pangan pada umumnya (Syahyuti, Sunarsih, Wahyuni, Sejati, \& Miftahul, 2015). Kebijakan pemerintah secara umum dituangkan melalui tiga pola program yaitu peningkatan produksi dan produktifitas melalui subsidi baik input, keuangan maupun bantuan teknis kepada petani, bantuan pangan langsung kepada masyarakat miskin dan intervensi perdagangan pangan melalui stabilisasi harga. Tujuan pemerintah tentu saja baik dalam membantu petani agar sejahtera dan memenuhi kebutuhan rakyatnya akan pangan. Walaupun demikian, secara tidak langsung hal ini juga dipengaruhi oleh kepentingan hasrat korporasi pangan multinasional untuk melakukan akumulasi modal dan memperluas pasar.

Secara umum, program pemerintah hanya mendukung satu jenis mode produksi yaitu pertanian sebagai industri. Pemerintah menerapkan subsidi dengan artikulasi yang terbatas dan pemaksaan logika pertanian industri. Dengan kata lain, petani harus mengikuti resep yang diberikan dari para ahli pertanian pemerintah. Jika petani tidak menuruti atau menolak maka tidak mendapatkan subsidi. Dengan demikian, suara aspirasi petani dan pengetahuan petani seringkali diabaikan sehingga program pertanian pemerintah hanya bermanfaat bagi petani dengan lahan yang luas dan subur, sementara petani kecil dan marginal tidak pernah benar-benar merasakan manfaat dari program. Bahkan dalam beberapa kasus, hal ini memicu terbentuknya kelas-kelas baru petani penguasa di perdesaan yang memfalitasi perampasan-perampasan kecil terhadap petani marginal yang tidak mampu bersaing (Li, 2012).

Pemberian bantuan pangan diimplementasikan menjadi pemberian beras murah untuk rakyat miskin (raskin). Disatu sisi, pemberian beras ini sangat membantu bagi mereka rakyat miskin diperkotaan tetapi di wilayah terpencil hal tersebut justru mengurangi keinginan petani untuk memberdayakan keanekaragaman sumber pangan yang mereka miliki dan menghambat pengarusutamaan pangan lokal di tingkat daerah. Selain itu, beras murah juga mengurangi kemampuan petani kecil dan gurem untuk bersaing sehingga membuat mereka harus meninggalkan pertanian beralih ke sektor yang lain. Hal tersebut semakin memperburuk ketersediaan pangan dan akses terhadap pangan terutama di daerah-daerah terpencil yang membuat kondisi perikehidupan masyarakatnya semakin rentan. Program pemerintah dalam melakukan stabilisasi harga semakin berkurang karena keterbatasan sumberdaya dan juga tekanan-tekanan untuk melakukan liberalisasi total pertanian. Pemerintah hanya mampu menjaga kestabilan komoditas utama itupun masih ada celah untuk melakukan penyelewengan kekuasaan.

Aspek kedaulatan pangan masuk ke dalam undang-undang terbaru tentang pangan No. 18 tahun 2012 bersama dengan konsep ketahanan pangan dan kemandirian pangan. Undang-undang pangan terbaru ini diharapkan dapat menjadi momentum bagi perubahan logika kebijakan pertanian maupun institusi pembangunan pertanian. Dengan adanya UU Pangan seharusnya negara menghormati, memenuhi, dan melindungi hak atas pangan warga negaranya dengan keberagaman cara, komoditas dan mode produksi pertanian. Diadopsinya kedaulatan pangan sebagai salah satu tujuan pembangunan pertanian nasional membutuhkan penyusunan rencana dan pendekatan pembangunan pangan yang berbeda (Syahyuti et al., 2015).

Selama hampir lima tahun berjalan sejak undang-undang ini disahkan belum ada implementasi yang jelas terkait aspek kedaulatan pangan. Beberapa wacana dan kebijakan yang berkembang masih terus menunjukkan nuansa paradigma ketahanan pangan. Bahkan ada beberapa pihak yang secara halus menolak dengan alasan usulan ini berasal dari pihak NGO (Syahyuti et al., 2015). untuk itu perlu dilakukan penelitian yang lebih mendalam mengenai persepsi program dengan nuansa kedaulatan pangan dari kacamata petani yang seringkali menjadi pihak yang paling lemah dalam rantai produksi pangan. Hal ini menjadi penting untuk dapat 
memberikan gambaran apa dan bagaimana seharusnya program ini dapat secara luwes berguna bagi petani dengan tetap memastikan kebutuhan pangan lokal tercukupi.

\section{Pandangan umum Kedaulatan}

Pangan versus Ketahanan Pangan

Kedaulatan Pangan. Kedaulatan

Pangan merupakan konsep dinamis yang dilatar belakangi oleh kekecawaan terhadap pembangunan pangan dan pertanian di berbagai negara (Syahyuti et al., 2015). Peningkatan Produksi dan produktivitas pertanian tidak serta-merta membuat sebagian petani di negara berkembang sejahtera, bahkan lebih jauh membuat ketimpangan akses pangan, ekonomi dan perdagangan semakin melebar, serta kerusakan permanen terhadap sumberdaya pertanian.

Salah satu penanda penting bagi evolusi perkembangan kedaulatan pangan adalah declaration of nyeleni yang disepakati Pada konferensi forum of food soverignity, di mana petani dan aktivis seluruh dunia bertemu untuk menyepakati definisi kedaulatan pangan yang kemudian diratifikasi oleh lembaga resmi pangan dunia FAO. Dalam deklarasi ini, kedaulatan pangan didefinisikan sebagai hak masyarakat terhadap pangan yang sehat dan sesuai dengan budayanya yang dihasilkan melalui metode yang berkelanjutan dan ramah lingkungan dan juga hak menentukan sistem pangan dan pertanian yang sesuai.

Kedaulatan pangan menempatkan aktoraktor yang memproduksi, mendistribusi dan yang mengkonsumsi sebagai fokus utama dalam sistem pangan dan kebijakan alih-alih sekedar memenuhi kebutuhan pasar dan korporasi. Kedaulatan pangan menekankan pada hak masyarakat, komunitas dan negara untuk mendefinisikan pertanian, perikanan dan peternakan sesuai dengan keadaan sosial, ekologis, ekonomi dan budaya yang unik. Hal ini mencakup hak atas pangan dan hak untuk memproduksinya serta hak terhadap sumber makanan, air, benih, plasma nutfah keanerakagaman hayati dan, kemampuan untuk mempertahankan diri mereka sendiri serta masyarakat meraka. Kedaulatan pangan berimplikasi pada hubungan sosial yang bebas dari segala penindasan dan ketidakadilan. (Declaration of Nyeleni , 2007), (Syahyuti et al., 2015).

Ketahanan Pangan. Definisi ketahanan pangan mengacu pada laporan World Food Summit tahun 1996 di Roma. Pada pertemuan tersebut disepakati bahwa ketahanan tercapai jika semua orang, setiap saat memiliki akses secara fisik dan ekomomi terhadap pangan, yang cukup, aman dan bergizi sesuai denga kebutuhan tubuh dan pilihan yang dikehendaki untuk dapat hidup secara sehat dan aktif (World Food Summit, 1996). Ditegaskan oleh (Jarosz, 2014) ketahanan pangan didefinisikan sebagai hak setiap orang untuk mendapatkan akses terhadap pangan yang aman dan bergizi hak ini sejalan dengan hak setiap orang untuk mendapatkan pangan dan cukup dan bebas dari kelaparan.

Tabel 1. Perbandingan Pendekatan Kedaulatan Pangan (Food Soverignity) dan ketahanan Pangan (Food Security)

\begin{tabular}{|c|c|c|}
\hline Discourse & Food Sovereignty & Food Security \\
\hline $\begin{array}{l}\text { Main } \\
\text { institutions }\end{array}$ & $\begin{array}{l}\text { Via Campesina, } \\
\text { International Planning } \\
\text { Committee on Food } \\
\text { Sovereignty; Global } \\
\text { March for Women; many } \\
\text { food justice and rights- } \\
\text { based movements }\end{array}$ & $\begin{array}{l}\text { International Bank for } \\
\text { Reconstruction and } \\
\text { Development (World } \\
\text { Bank); FAO; UN } \\
\text { Commission on } \\
\text { Sustainable Development; } \\
\text { USDA (Meerigan); } \\
\text { mainstream fair trade; } \\
\text { some Slow Food } \\
\text { Movement; some Food } \\
\text { Policy Councils; most } \\
\text { food banks and food aid } \\
\text { programs. }\end{array}$ \\
\hline Orientation & Entitlement & Development \\
\hline Model & $\begin{array}{l}\text { Dismantle corporate } \\
\text { agrifoods monopoly } \\
\text { power; parity; redistri- } \\
\text { butive land reform; } \\
\text { community right to water } \\
\text { and seed; regionally based } \\
\text { food system; } \\
\text { democratization of food } \\
\text { system; sustainable } \\
\text { livelihoods; protection } \\
\text { from dumping/ } \\
\text { overproduction; revival of } \\
\text { agroecologically managed } \\
\text { peasant agriculture to } \\
\text { distribute wealth and cool } \\
\text { the planet; regulated } \\
\text { markets and supply. }\end{array}$ & $\begin{array}{l}\text { Mainstreaming/certificati } \\
\text { on of niche markets (e.g. } \\
\text { organic, fair, local, } \\
\text { sustainable); maintaining } \\
\text { northern agricultural } \\
\text { subsidies; "sustainable" } \\
\text { roundtables for agrofuels, } \\
\text { soy, forest products, etc.; } \\
\text { market-led land reform }\end{array}$ \\
\hline $\begin{array}{l}\text { Approach } \\
\text { to the food } \\
\text { crisis }\end{array}$ & $\begin{array}{l}\text { Human right to food } \\
\text { sovereignty; locally } \\
\text { sourced, sustainably } \\
\text { produced, culturally } \\
\text { appropriate, } \\
\text { democratically controlled } \\
\text { focus on UN/FAO } \\
\text { negotiations }\end{array}$ & $\begin{array}{l}\text { Same as neoliberal but } \\
\text { with increased medium } \\
\text { farmer production and } \\
\text { some locally sourced foof } \\
\text { aid; more agricultural } \\
\text { aidbut tied to GMOs and } \\
\text { "bio-fortified/climate- } \\
\text { resistant" food. }\end{array}$ \\
\hline $\begin{array}{l}\text { Guiding } \\
\text { document }\end{array}$ & $\begin{array}{l}\text { Peoples Comprehensive } \\
\text { Framework for Action to } \\
\text { Eradicate Hunger }\end{array}$ & $\begin{array}{l}\text { World Bank } 2009 \\
\text { Development Report }\end{array}$ \\
\hline
\end{tabular}

Dalam deklarasi tersebut, akar dari kelaparan adalah kemiskinan. Orang miskin tidak dapat membeli pangan karena ketidakstabilan penawaran dan permintaan global terhadap pangan yang dipengaruhi oleh 
tekanan penduduk dan tekanan terhadap sumberdaya alam. Perdagangan diidentifikasi sebagai elemen kunci dimana mobilisasi teknologi dan bantuan pangan melalui intervensi pembangunan berkelanjutan di identifikasi sebagai respon kebijakan. Hak negara dalam menjamin kedaulatannya di bidang pangan diakui tetapi dalam prakteknya kedaulatan negara di batasi melalui "structural adjustment" dan pengakuan atas peran WTO serta perdagangan transnasional yang bersifat neoliberal dan mengurangi kemampuan nasional suatu negara untuk melakukan perlindungan terhadap kemandirian pangan di level nasional dan lokal. Kajian-kajian yang terkait ketahanan pangan menekankan pentingnya "good governance" dalam menjamin ketahanan pangan baik di linstitusi multirateral ditingkat international maupun di level nasional. Good governance dimaksudkan untuk meningkatkan penawaran dan aksesibilitas pangan melalui perdagangan pasar global atau peningkatan produksi pangan dengan mendorong investasi guna peningkatan produktivitas pertanian di berbagai tingkat.

Holt Giménez (2010) memberikan perbandingan antara kedua pendekatan melalui tabel dibawah ini, dapat dilihat perbedaan pendekatan antara kedaulatan pangan dan ketahanan pangan.

Posisi kedaulatan pangan dan ketahanan pangan menurut Syahyuti, (2014) adalah sejajar, karena yang membedakannya adalah elemen yang ada didalamnya. Namun, kesejajaran ini tidak serta merta dianggap congruent oleh sebagian ahli. Bernstein (2013) menganggap konsep ini tak lebih dari sebuah kumpulan emblem/simbol yang mewakili sikap yang berlawanan dengan diskursus dominan rezim pangan korporasi. Kedaulatan pangan lebih dianggap sebagai sikap politik, sementara operasionalisasi dan diseminasi konkrit kedaulatan pangan belum banyak teridentifikasi. Namun, gerakan LSM baik nasional maupun internasional memberikan berbagai penerapan konkrit dan panduan langkah pembangunan pertanian berlanggam kedaulatan pangan. Mulai dari pertanian berbasis agroekologi dan gerakangerakan pangan yang mengusung isu pangan lokal, sampai upaya-upaya perdagangan yang berkeadilan. Praktik-praktik pembangunan pertanian berbasis kedaulatan pangan masih terus berevolusi mencari bentuknya, akan tetapi polapolanya sudah terbentuk dan memiliki contoh konkrit. Gerakan semacam ini banyak bermunculan tetapi seringkali dianggap skalanya terlalu kecil, sangat lokal dan sporadis. Ada tiga hal yang perlu dikaji lebih lanjut mengenai pengarusutamaan kedaulatan pangan: 1) apakah karena keterbatasan sumberdaya pendukung gerakan tersebut yang sebagian besar adalah NGO? 2) karena kurang adanya dukungan dari para petani terhadap gerakan berbasis kedaulatan pangan? Ataukah 3) posisi kedaulatan pangan memiliki keterhubungan yang erat dengan konsep pembangunan pertanian yang lain seperti ketahanan pangan untuk dapat bertahan?. Oleh karena itu, Penelitian mengenai refleksi dan persepsi konsep kedaulatan pangan di tingkat petani dan masyarakat dan praktik yang melingkupinya sangat penting dilakukan untuk dapat menunjukkan potensi pengembangan dan pengarusutamaan dalam rangka memenuhi amanat undang-undang pangan dan harapan pemerintah untuk dapat mensejahterakan rakyatnya.

Tulisan ini merupakan kajian akademis kritis untuk menghindari bias kepentingan para penyokong kedaulatan pangan yang seringkali muncul dengan klaim-klaim sepihak, serta sifat hegemonik dari rezim pangan. Tulisan ini juga dapat menjadi bahan renungan bagi ahli-ahli pembangunan pertanian untuk dapat mulai mendiskusikan langkah-langkah perubahan untuk dapat mendukung pengarusutamaan kedaulatan pangan dengan menyesuaikan konteks dan kondisi faktual di Indonesia.

Penelitian ini dilakukan di Flores Timur, provinsi NTT dengan pertimbangan faktor keterjangkauan dan banyaknya masalah terkait pangan didaerah tersebut. Penelitian ini menjadi strategis karena terkait langsung dengan kepentingan petani dan rakyat yang hidup di wilayah yang jauh dari pusat pemerintahan karena jika aspek kedaulatan dapat benar-benar diakomodasi oleh negara maka merakalah yang menjadi pihak yang diuntungkan. selain itu wilayah ini juga memiliki ciri klimatologi yang unik berbeda dengan sebagaian besar wilayah indonesia sehingga diharapkan memberikan gambaran keberagaman iklim dan topografi serta komoditas berbagai wilayah di Indonesia. Flores Timur juga memiliki budaya dan karakter masyarakat yang khas dan memiliki kekayaan kearifan lokal terkait dengan pengelolaan sumberdaya alam dan pertanian.

Konteks Wilayah Flores Timur. Flores Timur terletak di ujung timur pulau Flores masuk dalam wilayah provinsi Nusa Tenggara Timur. 
Larantuka adalah ibukota kabupaten Flores Timur. Flores Timur memiliki tipikal iklim yang kering dibandingkan kepulauan lain di Indonesia. Kurang lebih $2.4 \times 10^{6}$ hektar dengan curah hujan kurang dari $1000 \mathrm{~mm}$ per tahun lebih dari $1.0 \mathrm{x}$ $10^{6}$ hektar terletak di provinsi Nusa tenggara timur (Jayaraju \& J Abdullah, 2013). Flores Timur memiliki kombinasi savana tropis dan pegunungan serta tebing. Flores Timur memiliki tiga gunung api aktif yaitu Ile Mandiri, Ile Boleng Dan Ile Bura.

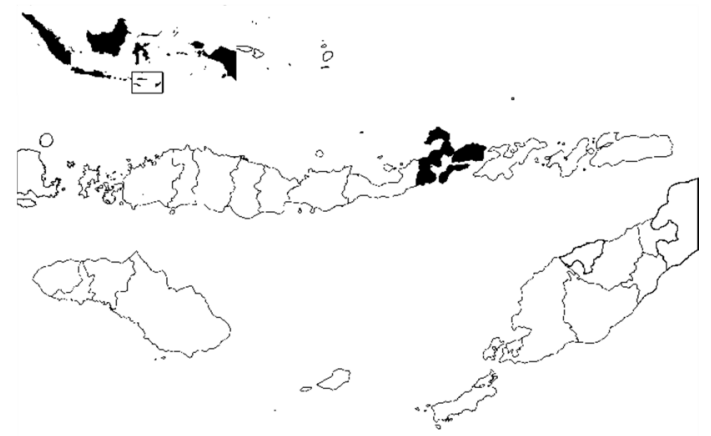

Gambar 1. Peta Flores Timur relatif terhadap Indonesia

Flores Timur dan Provinsi Nusa Tenggara Timur pada umumnya adalah wilayah yang memiliki tingkat kemiskinan yang cukup tinggi kurang lebih $65 \%$ rumah tangganya hidup dibawah garis kemiskinan (BPS, 2008). Kondisi geografis,

ketidakmerataan pembangunan infrasturktur dan iklim yang relatif kering menjadi salah satu penyebab kemiskinan (Bottema, Sukesi, $\&$ Seran, 2009). Lebih dari 80\% menggantung hidupnya di sektor pertanian. kegiatan pertanian di Flores Timur diantaranya menanam tanaman pangan seperti jagung, padi, singkong dan umbi-umbian lokal untuk konsumsi sehari-hari, peternakan skala kecil untuk memenuhi kebutuhan ekonomi lain dan kebutuhan ritual, dan mengelola perkebunan skala kecil dengan komoditas seperti jambu mete, kemiri, kopi, cengkeh dan cendana. Kondisi alam yang keras dan ketergantungan terhadap curah hujan membuat petani menghadapi resiko kegagalan yang cukup tinggi. akan tetapi, penduduk lokal telah beradaptasi sedemikian rupa dan mengembangkan pelbagai strategi untuk mengatasi hal tersebut (Bottema et al., 2009). Bayo, (2009) mengemukakan tentang minimnya kehadiran negara dalam menghadirkan pelayanan dasar kepada rakyat di Flores Timur. Dia menyimpulkan bahwa Flores Timur dianaktirikan oleh negara karena pada kenyataanya rakyat jarang bersinggungan dengan wajah welas asih negara terkait pelayanan umum, pendikan, kesehatan, listrik dan infrastrutur, alih-alih seringkali negara hadir dalam aksi-aksi pendisiplinan dan kegiatan represif atas nama penegakan hukum melalui polisi dan militer dalam konflikkonflik antara hukum adat dan hukum negara. Flores Timur menjadi tempat yang baik untuk melihat efek buruk dari dominasi kebijakan pangan yang tidak berpihak. Flores dikenal dengan masalah malnutrisi. Masalahnya buka ketidakadaan pangan tetapi minimnya pilihan dan hilangnya keberagaman jenis dan kebiasaan makan. Flores Timur sebelumnya memiliki beragam jenis pangan dan model pertanian untuk menyesuaikan diri dengan keadaan iklim yang tidak menentu dan kekeringan. Akan tetapi keberagaman jenis dan pola pangan tersebut mulai berkurang dan bahkan hilang setelah hampir 32 tahun berada dibawah dominasi kebijakan pangan monocroping, hal tersebut membuat Flores Timur semakin rentan dan rawan pangan. Masyarakat Flores Timur dikenal secara umum sebagai orang Lamaholot. Secara garis keturunan mereka berasal dari beberapa suku. mereka menyebut orang lamaholot karena kesamaan bahasa bukan karena berasal dari satu keturunan, terdapat keragaman sejarah asal-usul, suku, dialek, filosofi dan pola hidup (Taum, 1997). Flores Timur saat ini memliki keseragaman pola kebudayaan walaupun memiliki keragaman asal-usul dimasa lalu. Orang flores memiliki keterikatan erat dengan kampung dimana mereka tinggal dan hidup (Taum, 1997). Ikatan sosial mereka dengan kampung tempat mereka tinggal melampaui sejarah asal-usul dan pandangan politik. Selain kampung kelompok sosial yang penting adalah klan/marga. Kelompok sosial yang terkecil bukan keluarga tetapi lebih besar mencakup orang-orang dengan marga yang sama.

Terdapat tiga kekuatan besar yang mempengaruhi kehidupan keseharian mereka yaitu adat, Gereja (katolik) dan negara, akan tetapi adat-istiadat mendominasi sistem sosial Flores Timur sejak lama. Persaingan kekuasaan antara adat, gereja dan negara membentuk hubungan berlapis yang dinamis dengan adat sebagai lapisan intinya (Bayo, 2009). 


\section{METODE PENELITIAN}

Studi ini merupakan studi kualitatif deskriptif yang menggunakan pendekatan etnografis dalam pengambilan informasi. Data dikumpulkan melalui wawancara mendalam dan observasi partisipan dengan aktor-aktor kunci yang terkati dengan gerakan pangan lokal yang dilakukan oleh lembaga swadaya masyarakat lokal dan program petanian yang di laksanakan oleh pemerintah daerah.

\section{KERANGKA TEORI}

Implementasi Kebijakan pangan indonesia secara konsisten memperlihatkan dominasi konsep ketahanan pangan bahkan sampai ketika undang-undang resmi pangan mengadopsi konsep kedaulatan. Programprogram dan tatanan kebijakan logika pembangunan tidak berubah untuk mengakomodasi konsep kedaulatan pangan. sehingga dapat dikatakan kebijakan pangan yang mengarah kepada konsep ketahanan pangan dipengaruhi oleh karakter hegemonik Gramsci dari rezim pangan koorporasi. Gramsci mendefinisikan hegemoni sebagai kepemimpinan, dominasi, penguasaan berdasarkan persetujuan pandangan/ konsensus, "consent of led", sebuah proses menggiring orang untuk memandang suatu fenomena atau problematika sosial, ekonomi atau budaya dalam kerangka yang ditentukan oleh penguasa (Bates, 1975). Sebagai contoh resep umum di Indonesia mengenai pembangunan pertanian bahwa petani dapat meningkatkan taraf hidupnya dengan meningkatkan produksinya sehingga diharapkan pendapatannya juga naik dan mengupayakan akses ke pasar yang kebih menguntungkan.

Pandangan umum tersebut tertanam dan tersebar ke seluruh pemangku kepentingan kebijakan pangan dan pelaku pertanian. Jika pandangan mengenai pertanian telah tersebar dan menjadi kewajaran maka hegemoni telah berada fase yang paling akut yaitu fase ketenangan semu. Pandangan berbeda, ketidaksetujuan, perlawanan terhadap pandangan hegemoni (Counter-hegemony) selalu akan ada tetapi wujudnya akan menyatu dengan perilaku sehari-sehari. Untuk mengungkap hal tersebut maka kerangka analisa politik sehari-hari (Kerkvliet, 2009) dibutuhkan. Kerkvliet (2009) mendefiniskan politik keseharian sebagai tindakan orang atau sekelompok orang melakukan penyesuaian, pengaturan, persetujuan, melawan peraturan, norma dan kesepakan mengenai alokasi sumberdaya, pola produksi dan atau penguasa dengan ekspresi yang tidak kentara dan aksiaksi kecil dalam kehidupan sehari-hari yang tidak terorganisir atau terlihat sebagai sesuatu yang mengancam keadaan status quo. Kerkvliet (2009) mengkategorikan politik sehari-hari menjadi empat yaitu dukungan, penyesuaian, modifikasi, penghindaran /perlawanan. Di bawah ini dapat dilihat ilutrasi kerangka berpikir dalam penelitian ini.

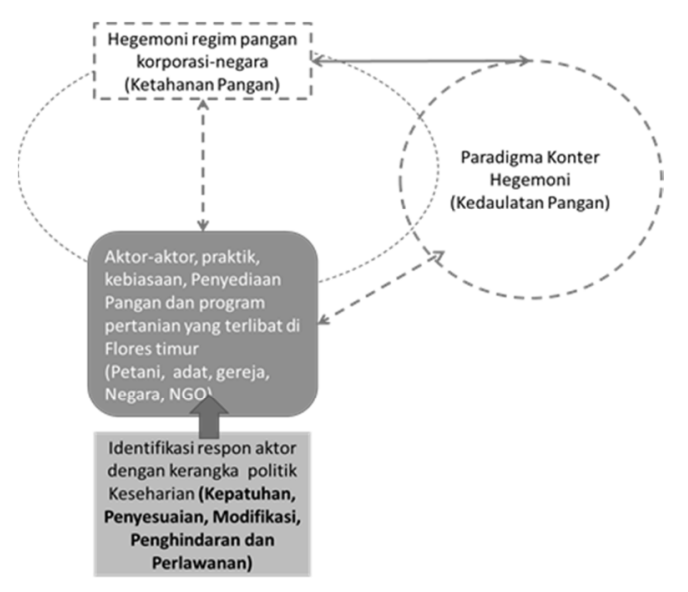

Gambar 2. Ilustrasi kerangka pikir penelitian

Dengan mengambil pendekatan hegemoni dan politik keseharian maka dibutuhkan interaksi yang intim dengan petani dan gerakan pangan lokal serta pemangku kepentingan, sehingga metode etnografi yang dipilih untuk mengumpulkan informasi dan data serta memahami cara pandang serta kebiasaan pelaku yang terlibat dalam kontestasi antar paradigma pangan di Flores Timur. Etnografi (Hammersley \& Atkinson, 2007) adalah proses kajian berdasarkan kerja lapangan menggunakan pelbagai teknik pengumpulan data (sebagian besar kualitatif) dengan secara langsung terlibat dengan realitas, konteks, pola kehidupan dan atau cara pikir mereka yang sedang menjadi objek studi dalam kurun waktu tertentu. Data dikumpulkan dengan metode indepth interview, participant observation terhadap aktor-aktor terkait yang gerakan pangan lokal yang dilakukan oleh lembaga swadaya masyarakat lokal dan program petanian yang di laksanakan oleh pemerintah daerah di Flores Timur. selain itu juga dilakukan kajian terhadap dokumendokumen, laporan dan catatan tertulis yang 
memiliki nilai informasi terkait maksud penelitian. Pengambilan data dan observasi dilakukan di empat desa di empat kecamatan sebagai representasi keragaman kondisi dan konteks kewilayahan di Flores Timur serta wawancara tokoh di pusat pemerintahan Flores Timur. keempat desa tersebut adalah Desa Pajinian, Kecamatan Adonara Barat, Desa Ratulodong Kecamatan Tanjung Bunga, Desa Serinuho kecamatan titihena dan Desa kawalelo kecamatan Demonpagong

\section{HASIL DAN PEMBAHASAN}

Karakteristik Politik Keseharian Petani Di Flores Timur. Dari hasil penelitian menunjukkan bahwa petani secara sadar memiliki sikap terhadap aktor-aktor kekuasaan (Adat, gereja dan negara). Mereka cendrung memilih menggunakan respon yang halus dan tertutup melalui cara-cara yang tersamarkan dengan perilaku remeh-temeh sehari-hari dalam mengungkapkan kesetujuan, penolakan maupun penyesuaian. Peta hubungan relasi kuasa di Flores Timur terkait pelbagai hal kehidupan petani termasuk diseminasi paradigma pembangunan pangan dapat dilihat pada gambar berikut.

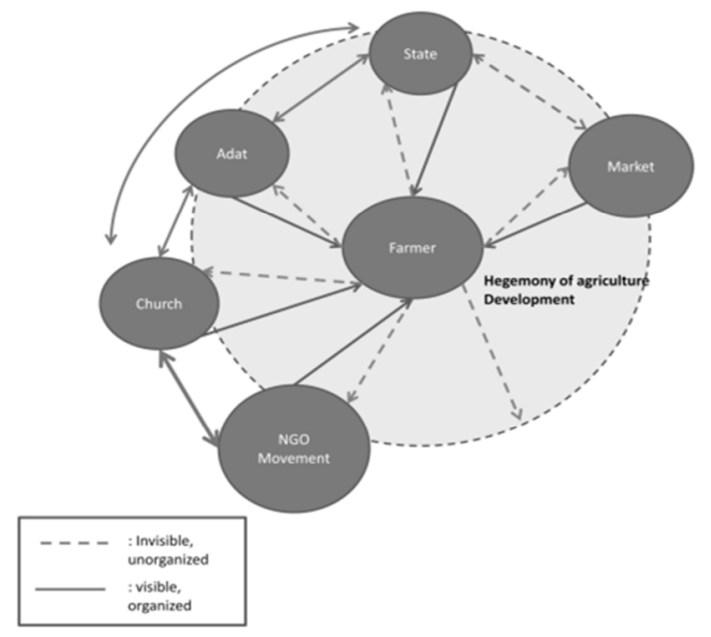

Gambar 3. Peta hubungan Petani dengan aktoraktor kuasa

Dari peta tersebut dapat didentifikasi aktor-aktor kuasa yang mempengaruhi petani. Hubungan antara petani dan adat dapat di kategorisasi sebagai hubungan yang mencerminkan dukungan (support) dan penyesuaian (compliance). Petani masih mempertahankan ritual adat selama mereka bisa dan mampu melakukannya, karena adat bagi mereka bukan hanya sebuah ritual semata tetapi sebuah upaya untuk menjamin hasil panen yang baik. Misalnya di desa Ratu lodong penanaman benih akan dimulai semenjak dilakukan ritual adat walaupun hujan belum turun, mereka percaya bahwa ritual adat akan mendatangkan hujan dan menjauhkan hama. Hubungan antara adat dan petani ini sangat bervariasi di Flores Timur, di beberapa tempat misalnya di desa kawalelo adat tidak diikuti secara ketat tetapi mereka masih melakukan beberapa ritual jika terdapat masalah atau perayaan khusus, misalnya jika ada serangan hama yang beruntun atau kemarau panjang. Kawalelo juga masih mengadopsi hukum tanah adat walaupun dalam perikehidupan mereka telah banyak menyesuaikan dengan kehidupan modern. Pada dasarnya mereka akan selalu berupaya mempertahankan adat walaupun pada akhirnya harus melakukan kompromi-kompromi dan penyesuaian.

Hubungan antara petani dan gereja disimbolkan dengan keimanan, misa minggi, pastor, sedekah dan patung jesus di dinding rumah. Petani di Flores Timur sebagian besar adalah individu yang religius. Pastor merupakan orang yang disegani di desa. Agama bagi mereka adalah sandaran bagi kehidupan mereka yang dihadapkan pada kesulitan-kesulitan. Elite gereja memiliki kekuasaan yang hampir sama dengan tetua adat dan Perwakilan pemerintah. Masyarakat menghormati mereka dan menuruti kata-kata mereka. ada dua hal yang menjadi sumber kekuatan bagi elit gereja, yaitu iman dan sumbangan. petani menurut karena mungkin tak hanya karena mereka beriman tetapi juga karena kesempatan untuk mendapatkan sumbangan ketika dalam kesulitan dari gereja. Di masyarakat secara umum memiliki pandangan mengenai elite gereja sakramen atau sak semen artinya memimpin misa/ sakramen atau membantu sak semen.

Hubungan antara petani dan pasar secara umum. Hampir semua petani terlibat dengan ekonomi pasar dari aspek terkecil seperti perdagangan dan uang sampai bisnis dan investasi. mereka berusaha menyesuaikan diri tetapi juga melakukan modifikasi pola hubungan ini. Modifikasi terlihat dari masih ditemukannya pola barter dalam transaksi hasil bumi dan jual beli sehari-hari walaupun pola ini semakin jauh berkurang digantikan dengan uang sebagai nilai tukar. Pengakuan terhadap ekonomi pasar dan kapital terlihat dari munculnya tokoh-tokoh baru yang dihormati 
dalam struktur masyarakat, tokoh yang memiliki kekayaan dan kekuatan modal, tokoh ini disebut ata kabelen. walaupun masih sedikit lebih kecil pengaruhnya dibandingkan tetua adat atau mereka dengan marga yang tinggi tetapi semakin lama pengaruh mereka semakin menguat.

Persaingan paradigma kedaulatan pangan dan ketahanan disimbolkan dengan pola hubungan antara petani dengan NGO melalui program pangan lokal dan Petani dengan Negara melalui program peningkatan produktivitas dan monocroping. Dalam tataran teori pertentangan kedua pendekatan pembangunan pangan ini terlihat jelas garis pembedanya. Kenyataanya, ditingkat petani pertentangan antara kedua pendekatan ini samar, terkait dan abu-abu. Dalam tulisan ini akan digambarkan mengenai pola-pola politik keseharian petani di empat desa yang mewakili karakter masyarakat Flores Timur disajikan pada Tabel 2.

Dari Tabel 2 dapat dilihat perbedaan desa satu dengan yang lain yaitu jarak, aksesibilitas, infrastruktur kesehatan dan pendidikan, ketersediaan air, sumberdaya pertanian dan strategi

Table ini memberikan gambaran secara umum mengenai perbedaan konteks kewilayahan dengan keberagaman respon terhadap program pangan NGO dan pemerintah. Setiap desa memiliki kesamaan diantaranya, etnis, kelompok bahasa, dan structure sosial dan semua desa masih memiliki pola pertanian subsisten untuk memenuhi kebutuhan pangan dan perkebunan skala kecil sebagai sumber pendapatan. perbedaan-perbedaan antar desa membuat petani memiliki perbedaan reaksi terhadap diskursus yang berkembang. dari tabel tersebut dapat di lihat bahwa semakin terbatasnya sumberdaya alam dan aksesibilitas, repon petani semakin mengarah pada respon penyesuaian terhadap diskursus yang berkembang sampai pada suatu batas dimana mereka hampir tidak memiliki akses terhadap sumberdaya alam dan tanah. Pada titik ini respon yang muncul dari petani adalah penghindaran dan perlawanan. Hal ini dapat

Tabel 2. Pola-pola Politik Keseharian Petani di Empat Desa yang Mewakili Karakter Masyarakat Flores Timur

\begin{tabular}{|c|c|c|c|c|}
\hline \multirow{2}{*}{ Karakteristik } & \multicolumn{4}{|c|}{ Desa } \\
\hline & Ratulodong & Kawalelo & Pajinian & Srinuho \\
\hline \multicolumn{5}{|l|}{ Perbedaan } \\
\hline Akses & $\begin{array}{l}\text { Angkutan umum, } \\
\text { sepeda motor, mobil } \\
\text { sewa }\end{array}$ & $\begin{array}{l}\text { Sepeda motor, mobil } \\
\text { sew }\end{array}$ & Perahu motor & $\begin{array}{l}\text { Sewa mobil, ojek } \\
\text { sepeda motor }\end{array}$ \\
\hline Jarak dari Larantuka & $28 \mathrm{~km}$ & $25 \mathrm{~km}$ & $15 \mathrm{~km}$ & $54 \mathrm{~km}$ \\
\hline Infrastructure & $\begin{array}{l}\text { SD, SMP, SMA } \\
\text { puskesmas, School, } \\
\text { jalan aspal }\end{array}$ & $\begin{array}{l}\text { SD, Puskesmas } \\
\text { pembantu, Jalan tanah } \\
\text { dan sirtu }\end{array}$ & $\begin{array}{l}\text { SD, SMP, Puskesmas } \\
\text { pembantu, Kapal kayu, } \\
\text { kapal ferry }\end{array}$ & $\begin{array}{l}\text { SD, Puskesmas } \\
\text { pembantu, Jalan semi } \\
\text { aspal }\end{array}$ \\
\hline Water availability & $\begin{array}{l}\text { Tersedia sepanjang } \\
\text { tahun melalui sumber } \\
\text { air yang dikelola oleh } \\
\text { mandiri oleh komunitas }\end{array}$ & $\begin{array}{l}\text { Terbatas, } \\
\text { Dari sumur atau dari } \\
\text { saluran air dari luar }\end{array}$ & $\begin{array}{l}\text { Ketersediaan air } \\
\text { terbatas, sumur pribadi } \\
\text { dan sumur komunal, } \\
\text { sumber air }\end{array}$ & $\begin{array}{l}\text { Banyak tersedia } \\
\text { sepanjang tahun } \\
\text { dikelola berdasarkan } \\
\text { kesepatan bersama }\end{array}$ \\
\hline $\begin{array}{l}\text { Potensi sumber daya } \\
\text { alam }\end{array}$ & $\begin{array}{l}\text { Perkebunan (Kelapa, } \\
\text { jambu mete, kemiri), } \\
\text { hasil hutan (madu) } \\
\text { Sayur }\end{array}$ & $\begin{array}{l}\text { Perikanan, Peternakan, } \\
\text { perkebunan kecil } \\
\text { jambu mete }\end{array}$ & $\begin{array}{l}\text { Perkebunan, perikanan, } \\
\text { sayur, olahan pangan }\end{array}$ & $\begin{array}{l}\text { Perkebunan, perikanan, } \\
\text { Hasil hutan, sayur, } \\
\text { buah }\end{array}$ \\
\hline $\begin{array}{l}\text { Tingkat kemiskinan } \\
\text { (BPS, 2015) }\end{array}$ & $12.3 \%$ & $13.6 \%$ & $26.3 \%$ & $16.5 \%$ \\
\hline $\begin{array}{l}\text { Penghidupan selain } \\
\text { pertanian }\end{array}$ & $\begin{array}{l}\text { Tenaga kerja tak } \\
\text { terampil, } \\
\text { Buruh Migran }\end{array}$ & $\begin{array}{l}\text { Pedagang, Buruh } \\
\text { Migran }\end{array}$ & $\begin{array}{l}\text { Pedagang, Buruh } \\
\text { Migran, tenaga kerja } \\
\text { kasar }\end{array}$ & $\begin{array}{l}\text { Buruh Migran, tenaga } \\
\text { kerja kasar }\end{array}$ \\
\hline $\begin{array}{l}\text { Peraturan Penguasaan } \\
\text { Lahan }\end{array}$ & Tanah adat komunal & Tanah adat komunal & $\begin{array}{l}\text { Tanah pribadi (hukum } \\
\text { negara berlaku) }\end{array}$ & Tanah adat komunal \\
\hline permasalahan & kelembagaan & Akses dan air & Keterbatasan lahan & $\begin{array}{l}\text { Konflik marga, dan } \\
\text { adat }\end{array}$ \\
\hline $\begin{array}{l}\text { Response petani } \\
\text { terhadap Program } \\
\text { pertanian pemerintah }\end{array}$ & $\begin{array}{l}\text { Modifikasi dan } \\
\text { penghindaran }\end{array}$ & $\begin{array}{l}\text { Penyesuaian dan } \\
\text { modifikasi, }\end{array}$ & $\begin{array}{l}\text { Modifikasi dan } \\
\text { penghindaran/perlawan } \\
\text { an }\end{array}$ & $\begin{array}{l}\text { Penyesuaian dan } \\
\text { modifikasi }\end{array}$ \\
\hline $\begin{array}{l}\text { Respon petani terhadap } \\
\text { Gerangan pangan lokal }\end{array}$ & $\begin{array}{l}\text { Dukungan dan } \\
\text { penyesuaian, }\end{array}$ & $\begin{array}{l}\text { Penyesuaian dan } \\
\text { modifikasi }\end{array}$ & $\begin{array}{l}\text { Modifikasi dan peng- } \\
\text { hindaran/perlawanan }\end{array}$ & $\begin{array}{l}\text { Penyesuaian dan } \\
\text { modifikasi }\end{array}$ \\
\hline
\end{tabular}

Sumber : (Hestiawan, 2016) 
dilihat pada fenomena di desa kawalelo dimana petani memiliki keterbatasan air, pangan dan pendapatan karena faktor alam dan iklim tetapi masih memiliki akses dan kontrol atas tanah dan sumberdaya alam melalui tanah komunal yang bisa diakses oleh semua orang. Mereka menunjukkan respon penyesuaian dan bersikap oportunis terhadap segala program. Akan tetapi jika kondisi ini diperparah oleh kehilangan akses/kontrol terhadap sumberdaya alam dan tanah seperti di desa pajinian, maka respon petani akan berubah menjadi perlawanan. Pajinian telah mengadopsi hukum negara tanah sehingga kepemilikan lahan secara pribadi. Hal ini membuat akses atas tanah hanya dimungkinkan melalui proses jual beli yang membutuhkan sumberdaya keuangan yang susah untuk mereka dapatkan dengan kondisi mereka. Dan keterlibatan sumberdaya keuangan telah memfasilitasi penguasaan tanah oleh sekelompok orang terhadap orang lain. Keterbatasan hasil dan meningkatnya kebutuhan hidup telah mendorong petani menggadaikan bahkan menjual tanahnya kepada orang lain untuk memenuhi kebutuhan hidup sehari-hari yang tak lagi dapat dipenuhi dari pertanian. sehingga mereka memutuskan untuk menjadi buruh migran, yang mana proses ini sangat berisiko. Banyak diantara petani yang menjadi buruh migran dan gagal diperantauan akhirnya harus kehilangan petak lahan terakhir mereka dan semakin jatuh kejurang kemiskinan. Hal ini dapat dibuktikan dengan tingginya tingkat kemiskinan di desa pajinian sebesar $26.3 \%$. Dengan pengalaman buruk terhadap proses pembangunan yang mereka alami tak ayal petani disini menunjukkan sikap perlawanan dan mencurigai program pembangunan pertanian dalam bentuk apapun.

\section{Keterkaitan dan kontestasi} Kedaulatan Pangan dan Ketahanan pangan di Flores Timur. Petani di Flores Timur berpartisipasi dalam ekonomi pasar dalam tiga peran yaitu sebagai produsen beberapa komoditas seperti Jambu mete, Kemiri, kelapa dan kopi. kedua sebagau konsumen produkproduk dari luar seperti beras, gula, minyak, tepung, perlatan rumah tangga dan peralatan kebersihan. ketiga petani berpartisipasi dalam pasar tenaga kerja baik buruh domesti maupun buruh migran. walupun berpartisipasi dalam pasar global, mereka bertahan pada praktik pertanian subsisten dan tetap menanam benih serta varietas lokal. Posisi yang paradox tersebut memperlihatkan kemampuan petani bertahan dan menyesuaikan diri. Mereka mempertahankan pertanian subsisten sebagai bagian dari budaya, sembari tetap mengikuti trend globalisasi dan ekspansi pembangunan bernuansa kapitalisme. Kontestasi antara ketahanan dan kedaulatan pangan dalam kehidupan sehari-hari terjadi secara samarsamar. Dalam gerakan yang menyadarkan kembali pangan lokal sebagai bagian dari paradigma kedaulatan pangan tidak terjadi kerusuhan maupun gejolak terbuka.Paradigma kedaulatan pangan sebenarnya telah terintegrasi dengan pola tradisi bertani turuntemurun mereka. Didalam hubungan mereka dengan pasar global tidak ditemukan keinginan yang tumpang tindih. mereka hanya bermaksud untuk melakukan diversifikasi strategi hidup mereka agar menjadi lebi nyaman. Dari hal tersebut dapat dikatakan bahwa ketahanan pangan dan kedaulatan di Flores Timur saling terkait. Ini senada dengan pernyataan Jarosz, (2014), dia menjelaskan bahwa paradigma kedaulatan pangan dan ketahanan pangan terkait satu sama lain, saling melengkap dan tidak saling bertolak belakang. Dia melanjutkan kedua diskursus ini dinamis, dan berubah seiring dengan kondisi, politik, budaya dan ekonomi sistem pangan di semua level. Ada beberapa hal dari konsep keterkaitan antar paradigma yang diungkapkan oleh (Jarosz, 2014) yang kurang sesuai . Memang benar ada keterkaitan antara paradigma tetapi menolak simplifikasi pertentangan kedua paradigma menjadi permasalahan teknis dan manajerial semata. Konsep keterkaitan gagal untuk menjelaskan reproduksi pemiskinan ditingkat petani seperti perampasan tanah dan kurangnya respek terhadap pengetahuan yang bersumber pada petani serta reproduksi keberpihakan kebijakan-kebijakan pertanian pemerintah kepada rezim pangan koorporasi yang difasilitasi oleh paradigma ketahanan pangan.

(Syahyuti et al., 2015) menyatakan sifat komplementer antara kedua konsep ini. dia memposisikan kedaulatan pangan sebagai strategi pokok untuk mencapai tujuan pembangunan pangan nasional, yakni ketahanan pangan. Kedaulatan pangan tidak mengantikan, namun menjadi pelengkap atau pendukung bahkan menjadi basis untuk tercapai-nya ketahanan pangan yang sejati. Pendapat dari syahyuti meneguhkan sifat hegemonik dari ketahanan pangan. kedaulatan 
pangan direduksi hanya menjadi konsep ideologis bukan praktis hal ini menjadikan sangat sulit untuk benar-benar meintegrasikan dan mewujudkan konsep kedaulatan pangan kedalam program yang nyata, karena kemungkinan konsep kedaulatan pangan dapat dikooptasi sedemikian untuk melanggengkan program yang sama sekali tidak memiliki paradigma kedaulatan pangan. sebagai contoh program-program UPSUS PAJALE upaya khusus padi, jagung kedelai, walaupun sudah mengadopsi keragaman dan diversifikasi dalam implementasinya masih menggunakan logika pembangunan pertanian yang dipengaruhi regim korporasi misalnya menggunakan bibit jagung hibrida alih-alih mengembangkan bibit lokal dari petani, mensupport penggunaan pupuk pabrikan alihalih menumbuhkan kemampuan petani dan unsur lokal untuk mengembangkan pupuk sesuai kebutuhan dan sumberdaya yang ada. Jika menggunakan logika yang komplementer maka dikhawatirkan kedaulatan pangan hanya dijadikan stempel dan legitimasi untuk program yang melanggengkan kekuasaan alihlaih tercapainya pembangunan pertanian yang berkeadilan sosial.

\section{Refleksi Kedaulatan Pangan}

Beberapa kajian (McMichael, 2008), (Schiavoni, 2014), (Iles \& Montenegro de Wit, 2014), (Shattuck, Schiavoni, \& VanGelder, 2015) menyarankan untuk menggunakan pandangan konsep multi-kedaulatan dalam rangka melakukan analisa terhadap kontradiksi dan fenomena yang muncul. konsep Multikedaulatan dapat dilakukan dengan mengaplikasikan berbagai sumber dan perspektif tentang sumber kedaulatan daripada hanya terbatas menggunakan hanya satu perspektif atau sumber kedaulatan. Segala macam pertentangan tentang kedaulatan pangan bersumber dari pertentangan teori dan praktis mengenai siapa dan apa itu "kedaulatan" dalam konsep kedaulatan pangan. (Edelman, 2014) menyatakan bahwa perbedaan dan pertentangan terhadap paradigma kedaulatan pangan baik yang menolak maupun menempatkan sebagai paradigma komplementer, menempatkan konsep kedaulatan di tempat yang berbeda diantaranya, negara-bangsa, wilayah, praktik lokal atau masyarakat. hal yang paling penting untuk dilakukan adalah memikirkan dan kemudian menghadapi tantangan politik dan kebijakan yang muncul akibat penerimaan yang berbedabeda terhadap kedaulatan pangan.
Pada konteks Flores Timur, pandangan mengenai konsep multi kedaulatan terlihat jelas. diantaranya adanya perbedaan sumber hukum tata guna lahan di keempat desa di Flores Timur, sebagian desa menggunakan sumber hukum adat yang intinya kepemilikan bersama tanah dan sumberdaya dan sebagian yang lain menggunakan sumber hukum negara yang mengakui kepemilikan dan penguasaan individu atas tanah. keberagaman sumberhukum di dalam suatu wilayah inilah yeng menunjukkan multi kedaulatan, pandangan tunggal mengenai kedaulatan negara-bangsa menjadi kurang relevan. jika menggunakan Konsep multi kedaulatan dan temuan-temuan dalam refleksi kedaulatan pangan di Flores Timur maka paradigma kedaulatan pangan dapat diarusutamakan kedalam kebijakan-kebijakan pembangunan pertanian pemerintah dan strategi pembangunann nasional. Hal ini menjadi penting sebab karena Indonesia dibangun atas dasar keberagaman dalam hal apapun tak terkecuali di bidang pertanian dan pangan. Undang-undang no. 18/2012 sebagai dasar hukum penyediaan pangan telah mengakomodasi kedaulatan pangan. Hal yang paling utama adalah mengubah pola hegemonik regime pangan pemerintah agar semakin memihak kepada kesejahteraan rakyat alih-alih mengakomodasi kepentingan koorporasi, akumulasi modal dan kekuasaan sehingga keadilan sosial dalam bidang pangan dapat dicapai. Perubahan pola ini harus dimulai dengan membuka pandangan dengan konsep praktik program bernuansa kedaulatan pangan seperti pertanian agroekologis, Dukungan terhadap benih dan tanaman lokal dan Pengetahuan pertanian, perikanan dan peternakan berbasis kearifan lokal, regulasi perdagangan pangan yang adil serta mendukung reforma agraria.

\section{KESIMPULAN}

Respon petani terhadap paradigma pembangunan pangan dan pertanian baik itu kedaulatan pangan dan ketahanan pangan di Flores Timur seringkali samar, baik itu respon mengenai persetujuan, penyesuaian maupun penolakan. Konsep kedaulatan pangan dapat berkembang baik dan diterima pada sebuah situasi dimana terdapat pengakuan terhadap berbagai sumber kedaulatan (adat, kearifan masyarakat dan kesepakatan) daripada dominasi satu pandangan kedaulatan misalnya 
kedaulatan negara. Negara dapat seharusnya memfasilitasi hal tersebut sedemikian sehingga sumber-sumber kedaulatan yang berbeda-beda tersebut dapat memeperkuat kedaulatan negara dalam hal pangan. Paradigma kedaulatan pangan dan ketahanan pangan ini menunjukkan keterkaitan baik dalam kebijakan maupun praktek kehidupan sehari-hari petani. konsep kedaulatan pangan tidak seharusnya ditempatkan dalam posisi komplementer maupun saling menggantikan tetapi saling sejajar dengan ketahanan pangan. jika hal tersebut dapat dilakukan maka, kecenderungan dominasi satu paradigma dapat dihindari dan tercapai keberagaman paradigma pembangunan pangan. Keberagaman paradigma dapat menjadi cara untuk menghindari efek-efek negatif dari rezim korporasi pangan global terhadap upaya-upaya pemenuhan hak rakyat atas pangan. Upaya mensejajarkan Konsep kedaulatan pangan dengan paradigma pembangunan pertanian dominan (ketahanan pangan dan kemandirian pangan) dalam kerangka kepentingan negara dapat dilakukan dengan langkah-langkah nyata dukungan terhadap program benih, pangan dan tanaman lokal, pertanian agroekologis, akomodasi terhadap pengetahuan-pengetahuan yang bersumber pada kearifan lokal dan memastikan regulasi perdagangan sehingga menciptakan perdagangan yang lebih adil serta memfasilitasi reforma agraria. konsep kedaulatan pangan di Indonesia merupakan konsep yang relatif baru tetapi pada kenyataanya beberapa elemen dari paradigma telah ada di dalam keseharian dan adat-istiadat kebudayaan masyarakat nusantara. Untuk itu diperlukan kajian mengenai unsur-unsur kebudayaan dan tradisi pertanian yang memiliki nuansa kedaulatan pangan. selain itu perlu juga diperlukan kajian-kajian akademis kritis mengenai gerakan-gerakan pangan lokal di daerah lain guna memperkuat definisi dan strategi penerapan paradigma kedaulatan pangan yang sesuai konteks Indonesia.

\section{UCAPAN TERIMAKASIH}

Penghargaan dan rasa terimakasih yang tulus kami persembahkan untuk semua pihak yang telah mendukung dalam kajian ini sebagai berikut Pieter de Vries (wageningen university), Nadya Karimasari (wageningen university), program studi development and rural Innovation Wageningen university, LPDP
Maria Loretha, Romo Benyamin Daud, Jerry Letor, Puji Sumedi, Yaspensel, YCAP, KEHATI, Zefrinus, Petrus Lamba Awang (IBEKA-East Sumba) dan seluruh teman, keluarga dan petani Flores Timur, Adonara, Larantuka, Lembata and Kupang

\section{DAFTAR PUSTAKA}

Bates, T. R. (1975). Gramsci and the Theory of Hegemony. Journal of the History of Ideas, 36(2), 351-366. doi: $10.2307 / 2708933$

Bayo, L. N. (2009). State Neglect, Church Decline, and Ascendent Adat: The Power Contestation in Adonara, Eastern Flores. Jurnal Ilmu Sosial Dan Ilmu Politik, 13(2), 149-171.

Bernstein, H. (2013). Food Sovereignty: A skeptical view. Food Sovereignty: A Critical Dialogue Food Sovereignty, \#1. doi:10.1590/15174522-017003912

Bottema, A., Sukesi, K., \& Seran, S. (2009). NTT at Crossroads. Report commissioned by UNRC to support the UNDAF Process. Retrieved from www.un.or.id/ documents_upload/.../NTT at a crossroads.pdf

BPS. (2008). NTT dalam Angka 2008. Retrieved from https://pustaka-ntt. googlecode. com/.../NTT dalam Angka 2008.

Edelman, M. (2014). The next stage of the food sovereignty debate. Dialogues in Human Geography, 4(2), 182-184. doi:10.1177/2043820614537153

Hammersley, M., \& Atkinson, P. (2007). Ethnography: Principles in Practice. Taylor \& Francis. Retrieved from https://books.google.nl/books?id=IK1AgAAQBAJ

Hestiawan, M. S. (2016). Reclaiming Diversity: The Practice And Everyday Politics Of A Local Food Movement In Flores Timur-Indonesia. Wageningen University.

Holt Giménez, E. (2010). Food Security, Food Justice, or Food Sovereignty. Food First Backgrounder, 16(4), 1-4.

Iles, A., \& Montenegro de Wit, M. (2014). Sovereignty at What Scale? An Inquiry into Multiple Dimensions of Food Sovereignty. Globalizations, 12(January 2015), 1-17. doi:10.1080/14747731.2014.957587

Jarosz, L. (2014). Comparing food security and food sovereignty discourses. Dialogues in Human Geography, 4(2), 
168-181. doi:10.1177/2043820614537161

Jayaraju, N., \& J Abdullah, K. (2013).

Developments in Soil Classification, Land Use Planning and Policy Implications. Developments in Soil Classification, Land Use Planning and Policy Implications, 4(25), 577-590. doi:10.1007/978-94-007-5332-7

Kerkvliet, T. B. J. (2009). Everyday politics in peasant societies (and ours). The Journal of Peasant Studies, 36(1), 227-243.

Li, T. M. (2012). To Make Live or Let Die? Rural Dispossession and the Protection of Surplus Populations. The Point Is to Change It: Geographies of Hope and Survival in an Age of Crisis, 41, 66-93. doi:10.1002/9781444397352.ch4

McMichael, P. (2008). Global citizenship and multiple sovereignties. In Y. Atasoy (Ed.), Hegemonic transitions, the state and crisis in neoliberal capitalism (pp. 23-42). Taylor \& Francis.

McMichael, P. (2009). A food regime analysis of the "world food crisis." Agriculture and Human Values, 26(4), 281-295. doi:10.1007/s10460-009-9218-5

Nyeleni. (2007). Declaration of Nyéléni. Forum for Food Sovereignty, (February).

Schiavoni, C. M. (2014). Working Paper
Competing sovereignties, contested processes The politics of food sovereignty construction, (583).

Shattuck, A., Schiavoni, C. M., \& VanGelder, Z. (2015). Translating the Politics of Food Sovereignty: Digging into Contradictions, Uncovering New Dimensions. Globalizations, 12(4), 421433. doi:10.1080/14747731.2015.1041243

Syahyuti. (2014). Mau ini apa itu? : komparasi konsep, teori dan pendekatan dalam pembangunan pertanian dan pedesaan (125 versus 125). Bogor: Amplitudo media science.

Syahyuti, Sunarsih, Wahyuni, S., Sejati, W. K., \& Miftahul, A. (2015). Kedaulatan Pangan Sebagai Basis untuk Mewujudkan Ketahanan Pangan Nasional Food Sovereignty as the Basis to Realize National Food Security. Forum Penelitian Agro Ekonomi, 33(2), 95-109.

Taum, Y. Y. (1997). Kisah Wato Wele-Lia Nurat dalam tradisi puisi lisan Flores Timur. Yayasan Obor Indonesia.

World Food Summit. (1996). Rome Declaration on World Food Security. World Food Summmit. Rome. Retrieved from http://www.fao.org/docrep/003/ w3613e/w3613e00.HTM 